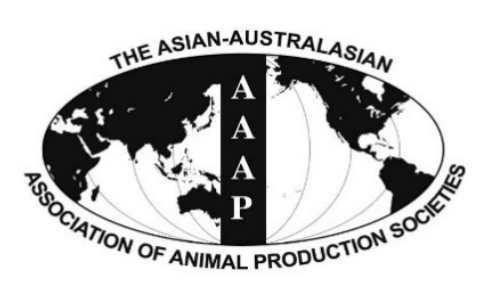

Open Access

Asian Australas. J. Anim. Sci.

Vol. 29, No. 11 : 1608-1615 November 2016

http://dx.doi.org/10.5713/ajas.16.0189

www.ajas.info

pISSN 1011-2367 elSSN 1976-5517

\title{
In vitro Solubility of Copper(II) Sulfate and Dicopper Chloride Trihydroxide for Pigs
}

\author{
C. S. Park and B. G. Kim* \\ Department of Animal Science and Technology, Konkuk University, Seoul 05029, Korea
}

\begin{abstract}
This study was conducted to determine the solubility of copper $(\mathrm{Cu})$ in two sources of copper(II) sulfate $(\mathrm{CuSO} 4)$ including monohydrate and pentahydrate and three sources of dicopper chloride trihydroxide (dCCTH) including $\alpha$-form (dCCTH- $\alpha$ ), $\beta$ form $(\mathrm{dCCTH}-\beta)$, and a mixture of $\alpha$ - and $\beta$-form $(\mathrm{dCCTH}-\alpha \beta)$ at different $\mathrm{pH}$ and a 3-step in vitro digestion assay for pigs. In Exp. 1, $\mathrm{Cu}$ sources were incubated in water-based buffers at $\mathrm{pH} 2.0,3.0,4.8$, and 6.8 for $4 \mathrm{~h}$ using a shaking incubator at $39^{\circ} \mathrm{C}$. The $\mathrm{CuSO} 4$ sources were completely dissolved within 15 min except at pH 6.8. The solubility of $\mathrm{Cu}$ in dCCTH- $\alpha$ was greater $(\mathrm{p}<0.05)$ than dCCTH$\beta$ but was not different from dCCTH- $\alpha \beta$ during 3-h incubation at $\mathrm{pH} 2.0$ and during 2-h incubation at $\mathrm{pH} 3.0$. At $\mathrm{pH} 4.8$, there were no significant differences in solubility of $\mathrm{Cu}$ in dCCTH sources. Copper in dCCTH sources were non-soluble at pH 6.8. In Exp. 2, the solubility of $\mathrm{Cu}$ was determined during the 3 -step in vitro digestion assay for pigs. All sources of $\mathrm{Cu}$ were completely dissolved in step 1 which simulated digestion in the stomach. In Exp. 3, the solubility of $\mathrm{Cu}$ in experimental diets including a control diet and diets containing $250 \mathrm{mg} / \mathrm{kg}$ of additional $\mathrm{Cu}$ from five $\mathrm{Cu}$ sources was determined during the in vitro digestion assay. The solubility of $\mathrm{Cu}$ in diets containing additional $\mathrm{Cu}$ sources were greater $(\mathrm{p}<0.05)$ than the control diet in step 1 . In conclusion, the solubility of $\mathrm{Cu}$ was influenced by $\mathrm{pH}$ of digesta but was not different among sources based on the in vitro digestion assay. (Key Words: Copper, In vitro Digestion, Solubility, Swine, Trace Mineral)
\end{abstract}

\section{INTRODUCTION}

Copper $(\mathrm{Cu})$ is essentially required for pigs to serve many functions in the body such as enzyme activations, immune functions, and hemoglobin synthesis (Hill and Spears, 2001). The NRC (2012) suggested that the requirements of $\mathrm{Cu}$ were 5 to $6 \mathrm{mg} / \mathrm{kg}$ for weanling pigs and 3 to $4 \mathrm{mg} / \mathrm{kg}$ for growing-finishing pigs in order to maintain normal metabolism. Many studies have reported that pharmacological concentrations of $\mathrm{Cu}$ in diets, ranged from 100 to $250 \mathrm{mg} / \mathrm{kg}$, improved growth performance of weanling pigs (Cromwell et al., 1998; Hill et al., 2000; Veum et al., 2004; Pérez et al., 2011; Shelton et al., 2011) and growing pigs (Cromwell et al., 1978; Zhao et al., 2014). Therefore, dietary $\mathrm{Cu}$ sources are generally used to enhance the growth performance of pigs especially in the postweaning phase. However, the action mechanism of the

\footnotetext{
* Corresponding Author: B. G. Kim. Tel: +82-2-2049-6255, Fax: +82-2-446-6255, E-mail: bgkim@konkuk.ac.kr Submitted Mar. 7, 2016; Revised Mar. 29, 2016; Accepted Jul. 1, 2016
}

growth-promoting effect of $\mathrm{Cu}$ is still debatable.

Many studies have been conducted to determine the possible mechanisms for growth-promoting effects of dietary Cu. Højberg et al. (2005) and Namkung et al. (2006) suggested that pharmacological concentration of dietary $\mathrm{Cu}$ reduced population of pathogenic bacteria in the gut and subsequently increased the growth performance of weanling pigs. In addition, Shurson et al. (1990) and Radecki et al. (1992) reported that dietary $\mathrm{Cu}$ improved the gut health of weanling pigs. On the other hand, Zhou et al. (1994) reported that intravenous injection of $\mathrm{Cu}$ improved the growth performance of weanling pigs. Whether dietary $\mathrm{Cu}$ improves the growth performance by affecting the condition of gastrointestinal tract, by promoting the systemic action, or both, liberation of $\mathrm{Cu}$ from the compound is critical to elucidate its growth-promoting mechanisms in pigs, which may be partially explained by in vitro solubility.

Copper(II) sulfate $\left(\mathrm{CuSO}_{4}\right)$ is widely used in swine diets as growth promoter and dicopper chloride trihydroxide (dCCTH), commonly known as tribasic copper chloride, is 
also used in swine diets to improve the growth performance of pigs (Shelton et al., 2011). Comparison among the in vitro solubility of $\mathrm{Cu}$ in these two products was conducted in the previous experiments (Pang and Applegate, 2006; 2007). However, to the best of our knowledge, the solubility of $\mathrm{Cu}$ in these two products has not been evaluated under the condition of pigs. Moreover, the solubility of $\mathrm{Cu}$ in $\mathrm{CuSO}_{4}$ may be affected by the degree of hydration and that of $\mathrm{Cu}$ in $\mathrm{dCCTH}$ may also be affected by the structure of its molecule. Therefore, the objective of this study was to determine the solubility of $\mathrm{Cu}$ in two sources of $\mathrm{CuSO}_{4}$ including monohydrate $\left(\mathrm{CuSO}_{4} \cdot \mathrm{H}_{2} \mathrm{O}\right)$ and pentahydrate $\left(\mathrm{CuSO}_{4} \cdot 5 \mathrm{H}_{2} \mathrm{O}\right)$ and three sources of $\mathrm{dCCTH}$ including $\alpha$ form (dCCTH- $\alpha), \beta$-form (dCCTH- $\beta)$, and a mixture of $\alpha-$ and $\beta$-form (dCCTH- $\alpha \beta)$ at different $\mathrm{pH}$ and a 3-step in vitro digestion assay for pigs.

\section{MATERIALS AND METHODS}

\section{Exp. 1}

Exp. 1 was conducted to determine the solubility of $\mathrm{Cu}$ in five sources of $\mathrm{Cu}$ at $\mathrm{pH} 2.0,3.0,4.8$, and 6.8 buffers during 4-h incubation. Two sources of $\mathrm{CuSO}_{4}$ including $\mathrm{CuSO}_{4} \cdot \mathrm{H}_{2} \mathrm{O}$ and $\mathrm{CuSO}_{4} \cdot 5 \mathrm{H}_{2} \mathrm{O}$ and three sources of dCCTH including dCСТН- $\alpha$, dCСТН- $\beta$, and $\mathrm{dCCTH}-\alpha \beta$ were analyzed in triplicate. The molecular structure of $\mathrm{dCCTH}$ was differentiated by its structure of surface, which can be observed by scanning electron microscopy (Figure 1). The dCCTH- $\alpha \beta$ consisted of $30 \%$ of $\alpha$-form and $70 \%$ of $\beta$-form. Each $\mathrm{Cu}$ source was weighed to contain $83.4 \mathrm{mg} \mathrm{Cu} / \mathrm{L}$ in the buffer solution and put into a $500-\mathrm{mL}$ conical flask. The concentration of $\mathrm{Cu}$ was the estimated concentration of $\mathrm{Cu}$ in digesta of pigs fed the diet containing $250 \mathrm{mg} / \mathrm{kg}$ of $\mathrm{Cu}$ and consumed water with a ratio relative to consumed feed at 2:1 (Pang and Applegate, 2007). A buffer solution (250 $\mathrm{mL}$ ) was added to a conical flask. Buffers were prepared by adding $1 \mathrm{M} \mathrm{HCl}$ for $\mathrm{pH} 2.0$ and 3.0, 10\% acetic acid for $\mathrm{pH}$ 4.8, and $0.1 M \mathrm{NaOH}$ for $\mathrm{pH} 6.8$ to distilled water. Buffers

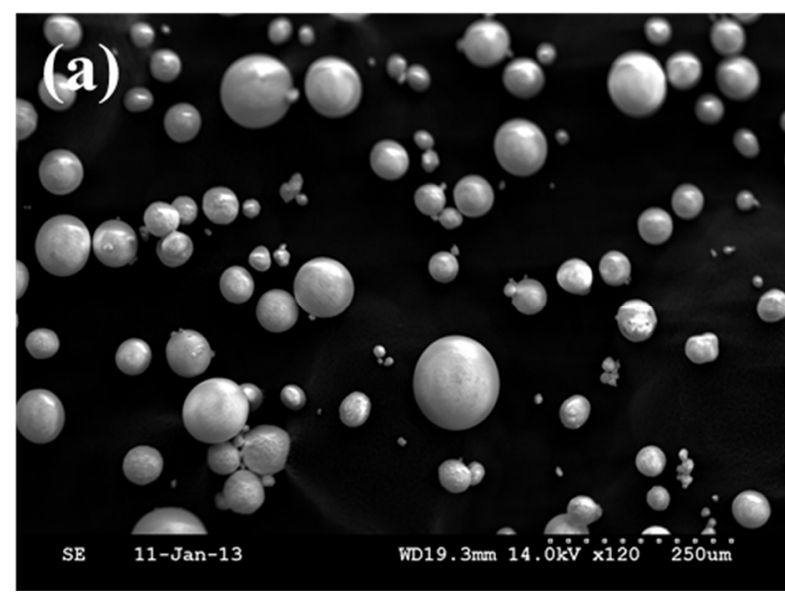

containing $\mathrm{Cu}$ sources were immediately incubated in a shaking incubator at $39^{\circ} \mathrm{C}$ for $4 \mathrm{~h}$. During the incubation, a $2 \mathrm{~mL}$ aliquot was collected at 15 and $30 \mathrm{~min}$ and 1, 2, 3, and $4 \mathrm{~h}$ after the beginning of the incubation. Each aliquot of sample was analyzed for the $\mathrm{Cu}$ concentration using an atomic absorption spectrophotometer (AAS; novAA300, Analytik Jena AG, Jena, Germany). Each subsample was diluted 1:5 with distilled water when the expected concentration of $\mathrm{Cu}$ in subsample exceeded the detection limit of AAS. The solubility of $\mathrm{Cu}$ was then determined by the following equation:

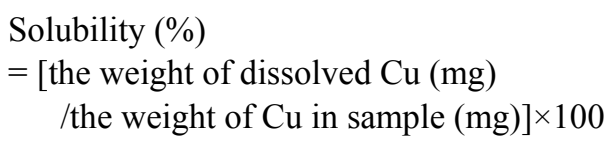

Exp. 2

Exp. 2 was conducted to determine the solubility of $\mathrm{Cu}$ in five sources of $\mathrm{Cu}$ during the 3-step in vitro digestion assay for pigs. Five sources of $\mathrm{Cu}$ including two sources of $\mathrm{CuSO}_{4}$ and three sources of $\mathrm{dCCTH}$ were the same as in Exp. 1 and analyzed in triplicate.

In vitro digestion assay consisted of 3 steps to simulate the digestion in the stomach, small intestine, and large intestine, respectively, based on the procedure of Boisen and Fernández (1997) with several modifications. Prior to the in vitro analysis, the final volume of solution (approximately $64.4 \mathrm{~mL}$ ) was adjusted to $250 \mathrm{~mL}$, and the volume of solutions used in each step was calculated. Each $\mathrm{Cu}$ source was weighed to contain $83.4 \mathrm{mg} \mathrm{Cu} / \mathrm{L}$ in the 250 $\mathrm{mL}$ of the final solution and put into a $500-\mathrm{mL}$ conical flask. In step 1 , sodium phosphate buffer solution $(0.1 \mathrm{M}, \mathrm{pH}$ 6.0) and $0.2 \mathrm{M} \mathrm{HCl}$ solution were added in flasks containing samples of interest. The estimated $\mathrm{pH}$ of mixed solution in the flask was 2.0. Thereafter, freshly prepared pepsin solution $(25 \mathrm{mg} / \mathrm{mL}$; $\geq 250$ units/mg solid, P7000, Pepsin from porcine gastric mucosa, Sigma-Aldrich, St. Louis, MO, USA) and chloramphenicol (C0378, Chloramphenicol,

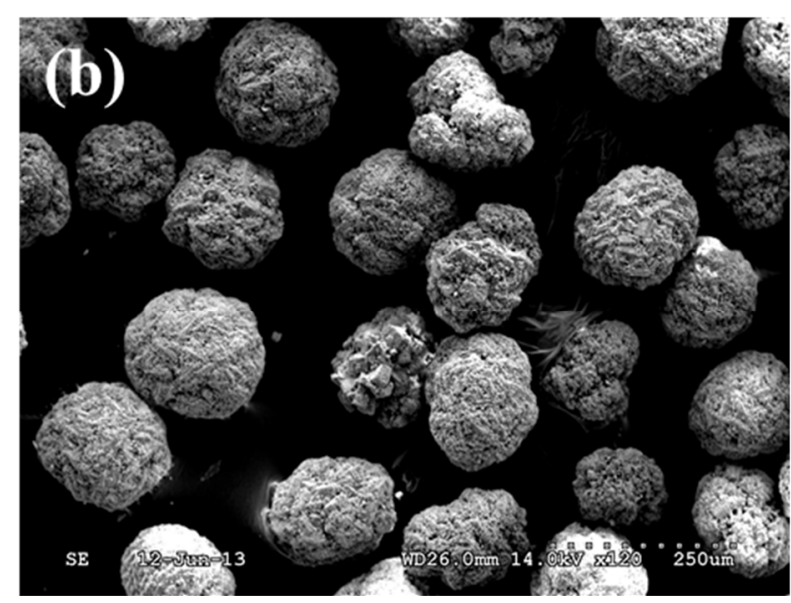

Figure 1. Scanning electron microscopy images of dicopper chloride trihydroxide consisted of $\alpha$-form (a) and $\beta$-form (b). 
Sigma-Aldrich, USA) solution (5 g/L ethanol) was added. Each test flask was sealed and incubated in a shaking incubator at $39^{\circ} \mathrm{C}$ for $2 \mathrm{~h}$. In step 2, sodium phosphate buffer solution (0.2 $M$, pH 6.8), 0.6 M NaOH solution, and freshly prepared pancreatin solution $(100 \mathrm{mg} / \mathrm{mL} ; 4 \times U S P$, P1750, Pancreatin from porcine pancreas, Sigma-Aldrich, USA) were added in the flasks, immediately after the step 1 incubation. The estimated $\mathrm{pH}$ of mixed solution in the flask was 6.8. The test flasks were then incubated in a shaking incubator at $39^{\circ} \mathrm{C}$ for $4 \mathrm{~h}$. In step 3, ethylenediaminetetraacetic acid solution $(0.2 \mathrm{M})$ was added in the flasks, and $\mathrm{pH}$ was adjusted to 4.8 by adding $30 \%$ acetic acid. Viscozyme (cellulolytic enzyme mixture, V2010, Viscozyme L, SigmaAldrich, USA) was added to simulate the microbial fermentation in the large intestine. The test flasks were then incubated in a shaking incubator at $39^{\circ} \mathrm{C}$ for $18 \mathrm{~h}$. An aliquot of sample $(2 \mathrm{~mL})$ was collected at the end of each step and subsequently diluted 1:10 or 1:20 with distilled water. The concentration of $\mathrm{Cu}$ in each subsample was analyzed using AAS. The solubility of $\mathrm{Cu}$ was calculated by the same equation in Exp. 1.

\section{Exp. 3}

Exp. 3 was conducted to determine the solubility of $\mathrm{Cu}$ in six experimental diets during the 3-step in vitro digestion assay for pigs. A control diet mainly containing corn and soybean meal was formulated (Table 1). Dried whey and fish meal were added in order to prepare the control diet for weanling pigs. The calculated concentration of $\mathrm{Cu}$ in the control diet was $17.9 \mathrm{mg} / \mathrm{kg}$. Five additional diets were formulated to contain $250 \mathrm{mg} / \mathrm{kg}$ of additional $\mathrm{Cu}$ as $\mathrm{CuSO}_{4} \cdot \mathrm{H}_{2} \mathrm{O}, \quad \mathrm{CuSO}_{4} \cdot 5 \mathrm{H}_{2} \mathrm{O}, \mathrm{dCCTH}-\alpha, \mathrm{dCCTH}-\beta$, and $\mathrm{dCCTH}-\alpha \beta$, respectively, at the expense of corn. Diets were formulated to meet or exceed the nutrient requirement estimates for 10 to $20 \mathrm{~kg}$ weanling pigs (NRC, 1998). The in vitro digestion assay was conducted based on the procedure of Boisen and Fernández (1997) without adjustment of the final volume. Thus, $500 \mathrm{mg}$ of experimental diets were analyzed in triplicate. A 2-mL aliquot collected at the end of each step was analyzed for the $\mathrm{Cu}$ concentration using AAS. The solubility of $\mathrm{Cu}$ was calculated by the same equation in Exp. 1 .

\section{Statistical analysis}

Data were analyzed by analysis of variance using general linear model procedure of SAS (SAS Inst. Inc., Cary, NC, USA). In Exp. 1 and 2, five sources of $\mathrm{Cu}$ were used as the independent variable. Experimental diets were used as the independent variable in Exp. 3. Least squares means for the solubility of $\mathrm{Cu}$ were calculated and separated by PDIFF option with the Tukey's adjustment. The experimental unit was the replicate and statistical significance was set at $\mathrm{p}<0.05$.

\section{RESULTS}

\section{Exp. 1}

The $\mathrm{CuSO}_{4}$ sources were completely dissolved within 15 min except at $\mathrm{pH} 6.8$ (Table 2). At pH 2.0, values for the solubility of $\mathrm{Cu}$ in $\mathrm{dCCTH}-\alpha$ and $\mathrm{dCCTH}-\alpha \beta$ were greater

Table 1. Ingredient composition (\%) of experimental diets (as-fed basis), Exp. 3

\begin{tabular}{|c|c|c|c|c|c|c|}
\hline \multirow{2}{*}{ Ingredient } & \multicolumn{6}{|c|}{ Diet $^{1}$} \\
\hline & Control & $\mathrm{CuSO}_{4} \cdot \mathrm{H}_{2} \mathrm{O}$ & $\mathrm{CuSO}_{4} \cdot 5 \mathrm{H}_{2} \mathrm{O}$ & $\mathrm{dCCTH}-\alpha$ & $\mathrm{dCCTH}-\beta$ & $\mathrm{dCCTH}-\alpha \beta$ \\
\hline Ground corn & 62.70 & 62.63 & 62.60 & 62.65 & 62.65 & 62.65 \\
\hline Soybean meal, $48 \%$ CP & 25.50 & 25.50 & 25.50 & 25.50 & 25.50 & 25.50 \\
\hline Dried whey & 5.00 & 5.00 & 5.00 & 5.00 & 5.00 & 5.00 \\
\hline Fish meal & 5.00 & 5.00 & 5.00 & 5.00 & 5.00 & 5.00 \\
\hline Limestone & 0.70 & 0.70 & 0.70 & 0.70 & 0.70 & 0.70 \\
\hline Monocalcium phosphate & 0.40 & 0.40 & 0.40 & 0.40 & 0.40 & 0.40 \\
\hline Salt & 0.40 & 0.40 & 0.40 & 0.40 & 0.40 & 0.40 \\
\hline Vitamin-mineral premix ${ }^{2}$ & 0.30 & 0.30 & 0.30 & 0.30 & 0.30 & 0.30 \\
\hline $\mathrm{CuSO}_{4} \cdot \mathrm{H}_{2} \mathrm{O}$ & - & 0.07 & - & - & - & - \\
\hline $\mathrm{CuSO}_{4} \cdot 5 \mathrm{H}_{2} \mathrm{O}$ & - & - & 0.10 & - & - & - \\
\hline $\mathrm{dCCTH}-\alpha$ & - & - & - & 0.05 & - & - \\
\hline $\mathrm{dCCTH-} \beta$ & - & - & - & - & 0.05 & - \\
\hline $\mathrm{dCCTH}-\alpha \beta$ & - & - & - & - & - & 0.05 \\
\hline
\end{tabular}

$\mathrm{CP}$, crude protein; $\mathrm{CuSO}_{4} \cdot \mathrm{H}_{2} \mathrm{O}$, copper sulfate monohydrate; $\mathrm{CuSO}_{4} \cdot 5 \mathrm{H}_{2} \mathrm{O}$, copper sulfate pentahydrate; dCCTH- $\alpha$, $\alpha$-form dicopper chloride trihydroxide; dCCTH- $\beta, \beta$-form dicopper chloride trihydroxide; dCCTH- $\alpha \beta$, a mixture of $\alpha$ - and $\beta$-form dicopper chloride trihydroxide.

${ }^{1}$ Each copper source was added to contain $250 \mathrm{mg} / \mathrm{kg}$ of additional copper.

${ }^{2}$ Provided the following quantities per $\mathrm{kg}$ of complete diet: vitamin A, 15,000 IU; vitamin $\mathrm{D}_{3}, 2,400 \mathrm{IU}$; vitamin E, $30 \mathrm{IU}$; vitamin $\mathrm{K}$, $3.0 \mathrm{mg}$; thiamin, $2.9 \mathrm{mg}$; riboflavin, $6.0 \mathrm{mg}$; pyridoxine, $2.9 \mathrm{mg}$; vitamin $\mathrm{B}_{12}, 0.04 \mathrm{mg}$; pantothenic acid, $22.5 \mathrm{mg}$; folic acid, $0.66 \mathrm{mg}$; niacin, $38 \mathrm{mg}$; biotin, $0.04 \mathrm{mg}$; copper, $15 \mathrm{mg}$ as copper sulfate; iron, $161 \mathrm{mg}$ as iron sulfate; iodine, $3.0 \mathrm{mg}$ as potassium iodate; manganese, $75 \mathrm{mg}$ as manganese sulfate; selenium, $0.23 \mathrm{mg}$ as sodium selenite; zinc, $188 \mathrm{mg}$ as zinc oxide; butylatedhydroxytoluene, $30 \mathrm{mg}$. 
Table 2. Solubility (\%) of copper in two sources of copper(II) sulfate and three sources of dicopper chloride trihydroxide at $\mathrm{pH} 2.0,3.0$, 4.8 , and 6.8 during 4 -h incubation ${ }^{1}$, Exp. 1

\begin{tabular}{|c|c|c|c|c|c|c|c|}
\hline \multirow{2}{*}{ Item } & \multicolumn{5}{|c|}{ Source of copper } & \multirow{2}{*}{ SEM } & \multirow{2}{*}{ p-value } \\
\hline & $\mathrm{CuSO}_{4} \cdot \mathrm{H}_{2} \mathrm{O}$ & $\mathrm{CuSO}_{4} \cdot 5 \mathrm{H}_{2} \mathrm{O}$ & $\mathrm{dCCTH}-\alpha$ & $\mathrm{dCCTH}-\beta$ & dCCTH- $\alpha \beta$ & & \\
\hline \multicolumn{8}{|l|}{ pH 2.0} \\
\hline $15 \mathrm{~min}$ & $104^{\mathrm{a}}$ & $106^{\mathrm{a}}$ & $42.5^{\mathrm{b}}$ & $17.2^{\mathrm{c}}$ & $34.9^{\mathrm{b}}$ & 2.07 & $<0.001$ \\
\hline $30 \mathrm{~min}$ & $104^{\mathrm{a}}$ & $105^{\mathrm{a}}$ & $50.3^{\mathrm{b}}$ & $26.2^{\mathrm{c}}$ & $45.7^{\mathrm{b}}$ & 1.75 & $<0.001$ \\
\hline $1 \mathrm{~h}$ & $105^{\mathrm{a}}$ & $107^{\mathrm{a}}$ & $67.8^{\mathrm{b}}$ & $44.7^{\mathrm{c}}$ & $63.8^{\mathrm{b}}$ & 1.82 & $<0.001$ \\
\hline $2 \mathrm{~h}$ & $105^{\mathrm{a}}$ & $105^{\mathrm{a}}$ & $89.9^{\mathrm{b}}$ & $72.8^{\mathrm{c}}$ & $89.8^{\mathrm{b}}$ & 1.73 & $<0.001$ \\
\hline $3 \mathrm{~h}$ & $106^{\mathrm{a}}$ & $107^{\mathrm{a}}$ & $107^{\mathrm{a}}$ & $98.3^{\mathrm{b}}$ & $105^{\mathrm{ab}}$ & 1.66 & 0.017 \\
\hline $4 \mathrm{~h}$ & 107 & 108 & 114 & 112 & 113 & 1.68 & 0.054 \\
\hline \multicolumn{8}{|l|}{ pH 3.0} \\
\hline $15 \mathrm{~min}$ & $105^{\mathrm{a}}$ & $106^{\mathrm{a}}$ & $5.21^{\mathrm{b}}$ & $0.04^{\mathrm{c}}$ & $2.22^{\mathrm{bc}}$ & 0.99 & $<0.001$ \\
\hline $30 \mathrm{~min}$ & $103^{\mathrm{a}}$ & $105^{\mathrm{a}}$ & $7.35^{\mathrm{b}}$ & $1.28^{\mathrm{c}}$ & $3.62^{\mathrm{bc}}$ & 0.98 & $<0.001$ \\
\hline $1 \mathrm{~h}$ & $104^{\mathrm{a}}$ & $108^{\mathrm{a}}$ & $12.0^{\mathrm{b}}$ & $5.50^{\mathrm{c}}$ & $8.52^{\mathrm{bc}}$ & 1.00 & $<0.001$ \\
\hline $2 \mathrm{~h}$ & $108^{\mathrm{a}}$ & $110^{\mathrm{a}}$ & $15.4^{\mathrm{b}}$ & $9.58^{\mathrm{c}}$ & $11.7^{\mathrm{bc}}$ & 1.16 & $<0.001$ \\
\hline $3 \mathrm{~h}$ & $107^{\mathrm{a}}$ & $109^{\mathrm{a}}$ & $18.9^{\mathrm{b}}$ & $14.6^{\mathrm{b}}$ & $16.3^{\mathrm{b}}$ & 1.32 & $<0.001$ \\
\hline $4 \mathrm{~h}$ & $108^{a}$ & $112^{\mathrm{a}}$ & $21.3^{\mathrm{b}}$ & $17.8^{\mathrm{b}}$ & $19.9^{\mathrm{b}}$ & 1.85 & $<0.001$ \\
\hline \multicolumn{8}{|l|}{$\mathrm{pH} 4.8$} \\
\hline $15 \mathrm{~min}$ & $110^{\mathrm{a}}$ & $116^{\mathrm{a}}$ & $0.29^{\mathrm{b}}$ & $0^{\mathrm{b}}$ & $0^{\mathrm{b}}$ & 4.17 & $<0.001$ \\
\hline $30 \mathrm{~min}$ & $113^{\mathrm{a}}$ & $117^{\mathrm{a}}$ & $0.94^{\mathrm{b}}$ & $0.07^{\mathrm{b}}$ & $0.32^{\mathrm{b}}$ & 5.15 & $<0.001$ \\
\hline $1 \mathrm{~h}$ & $112^{\mathrm{a}}$ & $117^{\mathrm{a}}$ & $1.53^{\mathrm{b}}$ & $0.31^{\mathrm{b}}$ & $0.80^{\mathrm{b}}$ & 4.08 & $<0.001$ \\
\hline $2 \mathrm{~h}$ & $111^{\mathrm{a}}$ & $118^{\mathrm{a}}$ & $2.16^{\mathrm{b}}$ & $0.53^{\mathrm{b}}$ & $1.14^{\mathrm{b}}$ & 3.56 & $<0.001$ \\
\hline $3 \mathrm{~h}$ & $112^{\mathrm{a}}$ & $117^{\mathrm{a}}$ & $2.57^{\mathrm{b}}$ & $0.70^{\mathrm{b}}$ & $1.32^{\mathrm{b}}$ & 2.99 & $<0.001$ \\
\hline $4 \mathrm{~h}$ & $110^{\mathrm{a}}$ & $116^{\mathrm{a}}$ & $2.82^{\mathrm{b}}$ & $0.97^{\mathrm{b}}$ & $1.68^{\mathrm{b}}$ & 3.33 & $<0.001$ \\
\hline \multicolumn{8}{|l|}{ pH 6.8} \\
\hline $15 \mathrm{~min}$ & $89.2^{\mathrm{b}}$ & $98.5^{\mathrm{a}}$ & $0^{c}$ & $0^{\mathrm{c}}$ & $0^{c}$ & 0.81 & $<0.001$ \\
\hline $30 \mathrm{~min}$ & $87.5^{\mathrm{b}}$ & $96.2^{\mathrm{a}}$ & $0^{\mathrm{c}}$ & $0^{\mathrm{c}}$ & $0^{\mathrm{c}}$ & 0.44 & $<0.001$ \\
\hline $1 \mathrm{~h}$ & $89.3^{\mathrm{b}}$ & $97.3^{\mathrm{a}}$ & $0^{\mathrm{c}}$ & $0^{\mathrm{c}}$ & $0^{\mathrm{c}}$ & 0.85 & $<0.001$ \\
\hline $2 \mathrm{~h}$ & $89.7^{\mathrm{b}}$ & $98.3^{\mathrm{a}}$ & $0^{c}$ & $0^{\mathrm{c}}$ & $0^{c}$ & 0.95 & $<0.001$ \\
\hline $3 \mathrm{~h}$ & $88.4^{\mathrm{b}}$ & $95.7^{\mathrm{a}}$ & $0^{c}$ & $0^{\mathrm{c}}$ & $0^{\mathrm{c}}$ & 1.19 & $<0.001$ \\
\hline $4 \mathrm{~h}$ & $88.7^{\mathrm{b}}$ & $95.8^{\mathrm{a}}$ & $0^{\mathrm{c}}$ & $0^{\mathrm{c}}$ & $0^{\mathrm{c}}$ & 0.33 & $<0.001$ \\
\hline
\end{tabular}

$\mathrm{CuSO}_{4} \cdot \mathrm{H}_{2} \mathrm{O}$, copper sulfate monohydrate; $\mathrm{CuSO}_{4} \cdot 5 \mathrm{H}_{2} \mathrm{O}$, copper sulfate pentahydrate; dCCTH- $\alpha, \alpha$-form dicopper chloride trihydroxide; $\mathrm{dCCTH}-\beta, \beta$ form dicopper chloride trihydroxide; dCCTH- $\alpha \beta$, a mixture of $\alpha$ - and $\beta$-form dicopper chloride trihydroxide; SEM, standard error of the mean.

${ }^{1}$ Each least squares mean represents 3 observations except $\mathrm{CuSO}_{4} \cdot \mathrm{H}_{2} \mathrm{O}$ for $4 \mathrm{~h}$ at $\mathrm{pH} 3.0$ ( 2 observations).

a,b,c Within a row, means without a common superscript letter differ $(\mathrm{p}<0.05)$.

$(\mathrm{p}<0.05)$ than dCCTH- $\beta$ during the 2 -h incubation. On $3 \mathrm{~h}$ of incubation, the solubility of $\mathrm{Cu}$ in $\mathrm{dCCTH}-\beta$ was less $(\mathrm{p}<0.05)$ than that of $\mathrm{Cu}$ in $\mathrm{dCCTH}-\alpha$, but was not different from that of $\mathrm{Cu}$ in $\mathrm{dCCTH}-\alpha \beta$. At the end of the incubation, the solubility of $\mathrm{Cu}$ was not different. In $\mathrm{pH} 3.0$ buffer, the solubility of $\mathrm{Cu}$ in $\mathrm{dCCTH}-\beta$ was less $(\mathrm{p}<0.05)$ than that of $\mathrm{Cu}$ in $\mathrm{dCCTH}-\alpha$, but was not different from dCCTH- $\alpha \beta$ until $2 \mathrm{~h}$ of incubation. After $3 \mathrm{~h}$, the solubility of $\mathrm{Cu}$ was not different among dCCTH sources. However, at the end of the incubation, values for the solubility of $\mathrm{Cu}$ in $\mathrm{dCCTH}$ sources were less than $22 \%$, and were also less $(p<0.05)$ than those of $\mathrm{Cu}$ in $\mathrm{CuSO}_{4}$ sources. At $\mathrm{pH} 4.8$, there were no significant differences among the solubility of $\mathrm{Cu}$ in dCCTH sources during the 4-h incubation. At the end of the incubation, values for the solubility of $\mathrm{Cu}$ in dCCTH sources were less than $3 \%$, and were also less $(p<0.05)$ than those of $\mathrm{Cu}$ in $\mathrm{CuSO}_{4}$ sources. In $\mathrm{pH} 6.8$ buffer, the solubility of $\mathrm{Cu}$ in $\mathrm{CuSO}_{4} \cdot 5 \mathrm{H}_{2} \mathrm{O}$ was greater $(\mathrm{p}<0.05)$ than that of $\mathrm{Cu}$ in $\mathrm{CuSO}_{4} \cdot \mathrm{H}_{2} \mathrm{O}$ during the overall incubation. The concentrations of $\mathrm{Cu}$ in samples collected from dCCTH sources were not detected during the overall incubation.

\section{Exp. 2}

Even though $\mathrm{Cu}$ in both $\mathrm{CuSO}_{4}$ and dCCTH sources were completely dissolved in step 1 , significant difference was observed $(\mathrm{p}<0.001)$ among the solubility of $\mathrm{Cu}$ (Table 3 ). However, values for the solubility of $\mathrm{Cu}$ in five $\mathrm{Cu}$ sources were not different in step 2 and 3.

\section{Exp. 3}

Values for the solubility of $\mathrm{Cu}$ in diets containing additional $\mathrm{Cu}$ sources were greater $(\mathrm{p}<0.05)$ than that of $\mathrm{Cu}$ in the control diet in step 1 (Table 4). However, after the step 2 incubation, values for the solubility of $\mathrm{Cu}$ in diets 
Table 3. Solubility (\%) of copper in two sources of copper(II) sulfate and three sources of dicopper chloride trihydroxide during 3-step in vitro digestion assay for pigs ${ }^{1}$, Exp. 2

\begin{tabular}{|c|c|c|c|c|c|c|c|}
\hline \multirow{2}{*}{ Item $^{2}$} & \multicolumn{5}{|c|}{ Source of copper } & \multirow{2}{*}{ SEM } & \multirow{2}{*}{ p-value } \\
\hline & $\mathrm{CuSO}_{4} \cdot \mathrm{H}_{2} \mathrm{O}$ & $\mathrm{CuSO}_{4} \cdot 5 \mathrm{H}_{2} \mathrm{O}$ & dCCТH- $\alpha$ & dCCТH- $\beta$ & dCCТН- $\alpha \beta$ & & \\
\hline$\overline{\text { Step } 1}$ & $101^{\mathrm{c}}$ & $101^{\mathrm{c}}$ & $108^{\mathrm{ab}}$ & $110^{\mathrm{a}}$ & $107^{\mathrm{b}}$ & 0.6 & $<0.001$ \\
\hline Step 2 & 106 & 106 & 113 & 114 & 109 & 2.8 & 0.191 \\
\hline Step 3 & 99 & 98 & 107 & 106 & 106 & 2.4 & 0.053 \\
\hline
\end{tabular}

$\mathrm{CuSO}_{4} \cdot \mathrm{H}_{2} \mathrm{O}$, copper sulfate monohydrate; $\mathrm{CuSO}_{4} \cdot 5 \mathrm{H}_{2} \mathrm{O}$, copper sulfate pentahydrate; $\mathrm{dCCTH}-\alpha, \alpha$-form dicopper chloride trihydroxide; dCCTH- $\beta, \beta-$ form dicopper chloride trihydroxide; $\mathrm{dCCTH}-\alpha \beta$, a mixture of $\alpha$ - and $\beta$-form dicopper chloride trihydroxide; SEM, standard error of the mean.

${ }^{1}$ Each least squares mean represents 3 observations.

${ }^{2}$ Each step represents the digestion in gastrointestinal tract: Step 1, stomach; Step 2, small intestine; Step 3, large intestine.

a,b,c Within a row, means without a common superscript letter differ $(\mathrm{p}<0.05)$.

containing $\mathrm{CuSO}_{4} \cdot \mathrm{H}_{2} \mathrm{O}$, dCCTH- $\alpha$, and dCCTH- $\beta$ were greater $(\mathrm{p}<0.05)$ than that of $\mathrm{Cu}$ in the control diet, but were not different from those of $\mathrm{Cu}$ in diets containing $\mathrm{CuSO}_{4} \cdot 5 \mathrm{H}_{2} \mathrm{O}$ and $\mathrm{dCCTH}-\alpha \beta$. At the end of the in vitro digestion assay, the solubility of $\mathrm{Cu}$ in the control diet was greater $(\mathrm{p}<0.05)$ than the diet containing $\mathrm{CuSO}_{4} \cdot 5 \mathrm{H}_{2} \mathrm{O}$ and $\mathrm{dCCTH}-\alpha \beta$, but was not different from the diet containing $\mathrm{CuSO}_{4} \cdot \mathrm{H}_{2} \mathrm{O}, \mathrm{dCCTH}-\alpha$, and dCCTH- $\beta$.

\section{DISCUSSION}

Although $\mathrm{Cu}$ has been used to improve the growth performance of both pigs (Cromwell, 2001) and poultry (Leeson, 2009), accurate mechanisms of $\mathrm{Cu}$ are not clearly identified. Previous studies suggested that growthpromoting effects of dietary $\mathrm{Cu}$ might be attributed to both antibacterial properties (Højberg, 2005; Namkung et al., 2006) and systemic actions (Zhou et al., 1994). To act as an antimicrobial agent, $\mathrm{Cu}$ should be dissolved in the gastrointestinal tract. Zevenhuizen et al. (1979) reported that the growth of $\mathrm{Cu}$-sensitive bacteria including Escherichia coli $\mathrm{B}$, Klebsiella aerogenes $\mathrm{H}$, and Alcaligenes Ad-4 was inhibited in $\mathrm{Cu}$-containing media in which $\mathrm{Cu}$ ion was derived from $\mathrm{CuSO}_{4}$ and ranged from 0.06 to 0.6 $\mathrm{mg} / \mathrm{kg}$. Pang et al. (2009) also reported from an in vitro experiment that the number of Escherichia coli in the ileal digesta of broiler decreased quadratically when incubated with the diets containing graded concentration of $\mathrm{Cu}$ up to
$250 \mathrm{mg} / \mathrm{kg}$ as $\mathrm{CuSO}_{4} \cdot 5 \mathrm{H}_{2} \mathrm{O}$. On the other hand, to act systemically so as to improve the growth performance of pigs (Zhou et al., 1994), $\mathrm{Cu}$ should be dissolved for absorption in the gastrointestinal tract (Hill and Spears, 2001). Therefore, dietary $\mathrm{Cu}$ sources may be dissolved in appropriate site of the gastrointestinal tract in order to improve the growth performance, and difference in solubility of $\mathrm{Cu}$ among $\mathrm{Cu}$ sources at various $\mathrm{pH}$ conditions can partially represent their properties as the growthpromoter.

In the current experiment, values for the solubility of $\mathrm{Cu}$ greater than $100 \%$ were commonly observed. These observations may be due to the analytical errors in the concentration of $\mathrm{Cu}$. Because the detection limit of AAS ranged from 0 to $20 \mathrm{mg} / \mathrm{L}$, subsamples collected in each time period were diluted in order to appropriately analyze the concentration of $\mathrm{Cu}$, which may cause the errors when determining the solubility of $\mathrm{Cu}$. Moreover, in Exp. 1, a 2 $\mathrm{mL}$ of aliquot was consistently collected from the $250 \mathrm{~mL}$ buffer solution containing each $\mathrm{Cu}$ source, and therefore, the volume of buffer was gradually reduced whenever the subsample was collected. On the contrary, in Exp. 2 and 3, the solutions involved in each digestion step were added after the prior step was finished and a $2 \mathrm{~mL}$ of aliquot was collected. Although the total volume of mixed solutions was adjusted when calculating the concentration of $\mathrm{Cu}$ at the end of each step, analytical errors may exist due to the increased number of solutions used in digestion. Due to the

Table 4. Solubility (\%) of copper in experimental diets containing two sources of copper(II) sulfate and three sources of dicopper chloride trihydroxide during 3 -step in vitro digestion assay for pigs ${ }^{1}$, Exp. 3

\begin{tabular}{|c|c|c|c|c|c|c|c|c|}
\hline \multirow{2}{*}{ Item $^{3}$} & \multicolumn{6}{|c|}{$\overline{\text { Diet }^{2}}$} & \multirow{2}{*}{ SEM } & \multirow{2}{*}{ p-value } \\
\hline & Control & $\mathrm{CuSO}_{4} \cdot \mathrm{H}_{2} \mathrm{O}$ & $\mathrm{CuSO}_{4} \cdot 5 \mathrm{H}_{2} \mathrm{O}$ & dCCТH- $\alpha$ & dCCTH- $\beta$ & dCCTH- $\alpha \beta$ & & \\
\hline$\overline{\text { Step } 1}$ & $46.7^{\mathrm{b}}$ & $99.3^{\mathrm{a}}$ & $82.2^{\mathrm{a}}$ & $90.6^{\mathrm{a}}$ & $95.9^{\mathrm{a}}$ & $85.2^{\mathrm{a}}$ & 4.17 & $<0.001$ \\
\hline Step 2 & $57.7^{\mathrm{b}}$ & $89.5^{\mathrm{a}}$ & $72.5^{\mathrm{ab}}$ & $81.2^{\mathrm{a}}$ & $82.0^{\mathrm{a}}$ & $74.3^{\mathrm{ab}}$ & 4.13 & 0.003 \\
\hline Step 3 & $93.2^{\mathrm{a}}$ & $81.9^{\mathrm{ab}}$ & $67.0^{\mathrm{b}}$ & $75.7^{\mathrm{ab}}$ & $78.9^{\mathrm{ab}}$ & $70.1^{b}$ & 4.49 & 0.017 \\
\hline
\end{tabular}

$\mathrm{CuSO}_{4} \cdot \mathrm{H}_{2} \mathrm{O}$, copper sulfate monohydrate; $\mathrm{CuSO}_{4} \cdot 5 \mathrm{H}_{2} \mathrm{O}$, copper sulfate pentahydrate; dCCTH- $\alpha$, $\alpha$-form dicopper chloride trihydroxide; dCCTH- $\beta, \beta$ form dicopper chloride trihydroxide; $\mathrm{dCCTH}-\alpha \beta$, a mixture of $\alpha$ - and $\beta$-form dicopper chloride trihydroxide; SEM, standard error of the mean.

${ }^{1}$ Each least squares mean represents 3 observations.

${ }^{2}$ Each copper source was added to contain $250 \mathrm{mg} / \mathrm{kg}$ of additional copper.

${ }^{3}$ Each step represents the digestion in gastrointestinal tract: Step 1, stomach; Step 2, small intestine; Step 3, large intestine.

a,b Within a row, means without a common superscript letter differ $(\mathrm{p}<0.05)$. 
cumulative addition of solutions in each step, values for the solubility of $\mathrm{Cu}$ in diets containing $\mathrm{Cu}$ sources in Exp. 3 may be reduced in step 2 and 3 .

In Exp. 1, the solubility of $\mathrm{Cu}$ in $\mathrm{CuSO}_{4} \cdot 5 \mathrm{H}_{2} \mathrm{O}$ was in agreement with the previously reported values (Pang and Applegate, 2006; 2007) except when incubated in $\mathrm{pH} 6.8$ buffer. In spite of greater $\mathrm{pH}$ condition, values for the solubility of $\mathrm{Cu}$ in $\mathrm{CuSO}_{4} \cdot 5 \mathrm{H}_{2} \mathrm{O}$ incubated in pH 6.8 buffer were greater than the values reported in Pang and Applegate (2006; 2007), which were $87.9 \%$ and $75.5 \%$, respectively. In addition, values for the solubility of $\mathrm{Cu}$ in $\mathrm{dCCTH}$ sources observed in Exp. 1 were less than the values reported in Pang and Applegate $(2006 ; 2007)$. This may be due to the fact that buffers used in the present experiment were different from those used in the previous reports (Pang and Applegate, 2006; 2007), which used $0.2 \mathrm{mM}$ Glycine$\mathrm{HCl}$ buffer for $\mathrm{pH} 2.5$ and $0.2 \mathrm{~m} M$ sodium acetate buffers for $\mathrm{pH} 5.5$ and 6.5 .

Copper(II) sulfate pentahydrate is dominantly used in swine diets (Shelton et al., 2011) and it has been used as a standard $\mathrm{Cu}$ source to estimate relative bioavailability of $\mathrm{Cu}$ in $\mathrm{Cu}$ sources for poultry (Guo et al., 2001; Miles et al., 2003). However, there is an increasing attention on the use of $\mathrm{CuSO}_{4} \cdot \mathrm{H}_{2} \mathrm{O}$ as an alternative to $\mathrm{CuSO}_{4} \cdot 5 \mathrm{H}_{2} \mathrm{O}$ because of its several benefits including less caking problems and better mixability in the mineral premix (Kim and Kil, 2015; Kim et al., 2016). In the present experiment, values for the solubility of $\mathrm{Cu}$ in $\mathrm{CuSO}_{4} \cdot \mathrm{H}_{2} \mathrm{O}$ were not different from $\mathrm{CuSO}_{4} \cdot 5 \mathrm{H}_{2} \mathrm{O}$ in $\mathrm{pH} 2.0,3.0$, and 4.8 buffers. Although values for the solubility of $\mathrm{Cu}$ in $\mathrm{CuSO}_{4} \cdot 5 \mathrm{H}_{2} \mathrm{O}$ were greater than those in $\mathrm{CuSO}_{4} \cdot \mathrm{H}_{2} \mathrm{O}$ during the 4-h incubation at $\mathrm{pH}$ 6.8 , it is likely that bioavailability and growth-promoting effects of $\mathrm{CuSO}_{4} \cdot \mathrm{H}_{2} \mathrm{O}$ is similar to $\mathrm{CuSO}_{4} \cdot 5 \mathrm{H}_{2} \mathrm{O}$ because both $\mathrm{Cu}$ sources have a similar chemical structure and are highly soluble in various $\mathrm{pH}$ conditions.

In $\mathrm{pH} 3.0$ buffer, values for the solubility of $\mathrm{Cu}$ in dCCTH sources were less than $22 \%$ during the $4-h$ incubation; in addition, solubility was less than $3 \%$ when incubated in $\mathrm{pH} 4.8$ buffers during the 4-h incubation. Copper in dCCTH sources were not dissolved in $\mathrm{pH} 6.8$ buffers for $4 \mathrm{~h}$. These observations were in agreement with Pang and Applegate $(2006 ; 2007)$ who reported that the solubility of $\mathrm{Cu}$ in dCCTH was decreased as the $\mathrm{pH}$ of buffer increased. Among dCCTH sources, dCCTH- $\beta$ was less soluble than $\mathrm{dCCTH}-\alpha$ during 3 -h incubation at $\mathrm{pH} 2.0$ and during 2-h incubation at $\mathrm{pH} 3.0$. Although dCCTH- $\alpha \beta$ contained more $\beta$-form than $\alpha$-form, values for the solubility of $\mathrm{Cu}$ in $\mathrm{dCCTH}-\alpha \beta$ were not different from $\mathrm{dCCTH}-\alpha$. To the best of our knowledge, there is limited information about the effects of molecular structure of $\mathrm{dCCTH}$ on the solubility of $\mathrm{Cu}$. Therefore, the reason why the solubility of $\mathrm{Cu}$ in dCCTH- $\beta$ was less than $\mathrm{dCCTH}-\alpha$ in low $\mathrm{pH}$ conditions remains unclear; however, it may be speculated that the solubility of $\mathrm{Cu}$ in $\mathrm{dCCTH}$ sources were affected by the $\mathrm{pH}$ of digesta greater than $\mathrm{CuSO}_{4}$ sources. Further research is needed to determine whether the structure of dCCTH affects the bioavailability and growthpromoting effects of $\mathrm{Cu}$.

In Exp. 2, all $\mathrm{Cu}$ sources were completely dissolved in step 1 of in vitro digestion assay. Compared to the result of Exp. 1, dCCTH sources were more soluble in sodium phosphate-based buffer than in water-based buffer; in addition, pepsin may increase the solubility of $\mathrm{Cu}$ in dCCTH sources. In Exp. 3, most of $\mathrm{Cu}$ in diets containing $\mathrm{Cu}$ sources were dissolved in step 1 of in vitro digestion assay. These observations suggest that $\mathrm{Cu}$ sources used in this experiment were readily available in the gastrointestinal tract of pigs. Pang and Applegate (2007) reported that the in vitro solubility of $\mathrm{Cu}$ might not accurately represent the bioavailability of $\mathrm{Cu}$ in broilers. Although it is impossible to exactly mimic the in vivo digestion in the in vitro digestion assay due to the physiological and environmental factors (Boisen and Eggum, 1991), the in vitro digestion procedure has been employed in the evaluation of feed ingredients (Park et al., 2012; Cervantes-Pahm et al., 2013), exogenous enzyme tests (Kong et al., 2015; Park et al., 2016), and mycotoxin sequestering agents (Kong et al., 2014). In the present work, as all $\mathrm{Cu}$ sources were dissolved in the solutions prepared to simulate the digestive tract of pigs, the solubility of $\mathrm{Cu}$ determined in the in vitro digestion assay for pigs may represent the bioavailability of $\mathrm{Cu}$ in $\mathrm{Cu}$ sources for pigs.

In Exp. 3, $\mathrm{Cu}$ in the control diet was less soluble in step 1 than that in diets containing additional $250 \mathrm{mg} / \mathrm{kg}$ of $\mathrm{Cu}$. This may be due to the smaller amount of $\mathrm{Cu}$ in the control diet compared with other diets. Dissolution of $\mathrm{Cu}$ in the control diet may be inhibited by other feed ingredients because the proportion of $\mathrm{Cu}$ is less than other diets. Significant differences were not observed in the solubility of $\mathrm{Cu}$ among diets containing $\mathrm{Cu}$ sources in all steps, which may indicate that bioavailability of $\mathrm{Cu}$ might not be different among $\mathrm{Cu}$ sources. Cromwell et al. (1998) reported that both $\mathrm{CuSO}_{4}$ and $\mathrm{dCCTH}$ addition improved the growth performance of weanling pigs and the growth performance of pigs fed diets containing pharmacological concentrations of $\mathrm{CuSO}_{4}$ were not different from that of pigs fed diets containing the same concentrations of dCCTH. However, Shelton et al. (2011) observed better growth performance of weanling pigs fed the diet containing $125 \mathrm{mg} / \mathrm{kg}$ of $\mathrm{Cu}$ as $\mathrm{CuSO}_{4}$ compared with that of weanling pigs fed the diet containing the same concentration of $\mathrm{Cu}$ as dCCTH. Pang et al. (2009) also reported that the population of lactobacilli increased and that of Escherichia coli decreased with increased concentration of $\mathrm{CuSO}_{4} \cdot 5 \mathrm{H}_{2} \mathrm{O}$, but the effects of dCCTH on the microbial populations were not observed. Further 
research is needed to determine the relative bioavailability of dCCTH compared with $\mathrm{CuSO}_{4}$.

In conclusion, $\mathrm{CuSO}_{4} \cdot \mathrm{H}_{2} \mathrm{O}$ and $\mathrm{CuSO}_{4} \cdot 5 \mathrm{H}_{2} \mathrm{O}$ were completely dissolved at $\mathrm{pH}$ 2.0, 3.0, and 4.8 within $15 \mathrm{~min}$. Values for the solubility of $\mathrm{Cu}$ in $\mathrm{CuSO}_{4}$ sources were greater than those of $\mathrm{Cu}$ in dCCTH sources during 4-h incubation at $\mathrm{pH} 3.0,4.8$, and 6.8. The solubility of $\mathrm{Cu}$ in $\mathrm{dCCTH}-\alpha$ was greater than that in $\mathrm{dCCTH}-\beta$ but was not different from that in $\mathrm{dCCTH}-\alpha \beta$ during 3-h incubation at $\mathrm{pH} 2.0$ and during 2-h incubation at $\mathrm{pH}$ 3.0. Copper sulfate sources and $\mathrm{dCCTH}$ sources were completely dissolved during the step 1 of in vitro digestion assay. Significant differences were not observed among the solubility of $\mathrm{Cu}$ in diets containing $\mathrm{Cu}$ sources during the in vitro digestion assay, but the solubility of $\mathrm{Cu}$ in the control diet was less than that of $\mathrm{Cu}$ in diets containing $\mathrm{Cu}$ sources in step 1 . These results indicated that $\mathrm{CuSO}_{4}$ sources are more soluble than $\mathrm{dCCTH}$ sources and the solubility of dCCTH sources are affected by both $\mathrm{pH}$ of digesta and their molecular structure.

\section{ACKNOWLEDGMENTS}

This paper was supported by the Rural Development Administration (Republic of Korea; PJ010932).

\section{REFERENCES}

Boisen, S. and J. A. Fernández. 1997. Prediction of the total tract digestibility of energy in feedstuffs and pig diets by in vitro analyses. Anim. Feed Sci. Technol. 68:277-286.

Boisen, S. and B. O. Eggum. 1991. Critical evaluation of in vitro methods for estimating digestibility in simple-stomach animals. Nutr. Res. Rev. 4:141-162.

Cervantes-Pahm, S., B. K. Knapp, B. G. Kim, Y. Liu, C. M. Parsons, G. C. Fahey Jr., and H. H. Stein. 2013. Comparison of two different in vivo models and an in vitro model for caloric determination of four novel fiber ingredients. J. Agric. Food Chem. 61:12374-12379.

Cromwell, G. L. 2001. Antimicrobial and promicrobial agents. In: Swine Nutrition. 2nd edn. (Eds. A. J. Lewis and L. L. Southern). CRC Press, Washington, DC, USA. pp. 401-426.

Cromwell, G. L., V. W. Hays, and T. L. Clark. 1978. Effect of copper sulfate, copper sulfide and sodium sulfide on performance and copper stores of pigs. J. Anim. Sci. 46:692698.

Cromwell, G. L., M. D. Lindemann, H. J. Monegue, D. D. Hall, and D. E. Orr, Jr. 1998. Tribasic copper chloride and copper sulfate as copper sources for weanling pigs. J. Anim. Sci. 76:118-123.

Guo, R., P. R. Henry, R. A. Holwerda, J. Cao, R. C. Littell, R. D. Miles, and C. B. Ammerman. 2001. Chemical characteristics and relative bioavailability of supplemental organic copper sources for poultry. J. Anim. Sci. 79:1132-1141.

Hill, G. M., G. L. Cromwell, T. D. Crenshaw, C. R. Dove, R. C. Ewan, D. A. Knabe, A. J. Lewis, G. W. Libal, D. C. Mahan, G.
C. Shurson, L. L. Southern, and T. L. Veum. 2000. Growth promotion effects and plasma changes from feeding high dietary concentrations of zinc and copper to weanling pigs (regional study). J. Anim. Sci. 78:1010-1016.

Hill, G. M. and J. W. Spears. 2001. Trace and ultratrace elements in swine nutrition. In: Swine Nutrition. 2nd edn. (Eds. A. J. Lewis and L. L. Southern). CRC Press, Washington, DC, USA. pp. 229-261.

Højberg, O., N. Canibe, H. D. Poulsen, M. S. Hedemann, and B. B. Jensen. 2005. Influence of dietary zinc oxide and copper sulfate on the gastrointestinal ecosystem in newly weaned piglets. Appl. Environ. Microbiol. 71:2267-2277.

Leeson, S. 2009. Copper metabolism and dietary needs. Worlds Poult. Sci. J. 65:353-366.

Kim, J. W. and D. Y. Kil. 2015. Determination of relative bioavailability of copper in tribasic copper chloride to copper in copper sulfate for broiler chickens based on liver and feather copper concentrations. Anim. Feed Sci. Technol. 210:138-143.

Kim, J. W., J. H. Kim, J. E. Shin, and D. Y. Kil. 2016. Relative bioavailability of copper in tribasic copper chloride to copper in copper sulfate for laying hens based on egg yolk and feather copper concentrations. Poult. Sci. 95:1591-1597.

Kong, C., C. S. Park, and B. G. Kim. 2015. Effects of an enzyme complex on in vitro dry matter digestibility of feed ingredients for pigs. Springerplus 4:261.

Kong, C., S. Y. Shin, and B. G. Kim. 2014. Evaluation of mycotoxin sequestering agents for aflatoxin and deoxynivalenol: An in vitro approach. Springerplus 3:346.

Miles, R. D., P. R. Henry, V. C. Sampath, M. Shivazad, and C. W. Comer. 2003. Relative bioavailability of novel amino acid chelates of manganese and copper for chicks. J. Appl. Poult. Res. 12:417-423.

Namkung, H., J. Gong, H. Yu, and C. F. M. de Lange. 2006. Effect of pharmacological intakes of zinc and copper on growth performance, circulating cytokines and gut microbiota of newly weaned piglets challenged with coliform lipopolysaccharides. Can. J. Anim. Sci. 86:511-522.

NRC (National Research Council). 1998. Nutrient Requirements of Swine. 10th edn. National Academy Press, Washington, DC, USA.

NRC (National Research Council). 2012. Nutrient Requirements of Swine. 11th edn. National Academy Press, Washington, DC, USA.

Pang, Y. and T. J. Applegate. 2006. Effects of copper source and concentration on in vitro phytate phosphorus hydrolysis by phytase. J. Agric. Food Chem. 54:1792-1796.

Pang, Y. and T. J. Applegate. 2007. Effects of dietary copper supplementation and copper source on digesta $\mathrm{pH}$, calcium, zinc, and copper complex size in the gastrointestinal tract of the broiler chicken. Poult. Sci. 86:531-537.

Pang, Y., J. A. Patterson, and T. J. Applegate. 2009. The influence of copper concentration and source on ileal microbiota. Poult. Sci. 88:586-592.

Park, C. S., A. R. Son, and B. G. Kim. 2012. Prediction of gross energy and digestible energy in copra meal, palm kernel meal, and cassava root fed to pigs. J. Anim. Sci. 90:221-223.

Park, K. R., C. S. Park, and B. G. Kim. 2016. An enzyme complex increases in vitro dry matter digestibility of corn and wheat in pigs. Springerplus 5:598. 
Pérez, V. G., A. M. Waguespack, T. D. Bidner, L. L. Southern, T. Veum, T. L., M. S. Carlson, C. W. Wu, D. W. Bollinger, and M. R. M. Fakler, T. L. Ward, M. Steidinger, and J. E. Pettigrew. 2011. Additivity of effects from dietary copper and zinc on growth performance and fecal microbiota of pigs after weaning. J. Anim. Sci. 89:414-425.

Ellersieck. 2004. Copper proteinate in weanling pig diets for enhancing growth performance and reducing fecal copper excretion compared with copper sulfate. J. Anim. Sci. 82:10621070 .

Radecki, S. V., P. K. Ku, M. R. Bennink, M. T. Yokoyama, and E. R. Miller. 1992. Effect of dietary copper on intestinal mucosa enzyme activity, morphology, and turnover rates in weanling pigs. J. Anim. Sci. 70:1424-1431.

Shelton, N. W., M. D. Tokach, J. L. Nelssen, R. D. Goodband, S. S. Dritz, J. M. DeRouchey, and G. M. Hill. 2011. Effects of copper sulfate, tri-basic copper chloride, and zinc oxide on weanling pig performance. J. Anim. Sci. 89:2440-2451.

Shurson, G. C., P. K. Ku, G. L. Waxler, M. T. Yokoyama, and E. R. Miller. 1990. Physiological relationships between microbiological status and dietary copper levels in the pig. J. Anim. Sci. 68:1061-1071.

Zevenhuizen, L. P. T. M., J. Dolfing, E. J. Eshuis, and I. J. Scholten-Koerselman. 1979. Inhibitory effects of copper on bacteria related to the free ion concentration. Microb. Ecol. 5:139-146.

Zhao, J., G. Allee, G. Gerlemann, L. Ma, M. I. Gracia, D. Parker, M. Vazquez-Anon, and R. J. Harrell. 2014. Effects of a chelated copper as growth promoter on performance and carcass traits in pigs. Asian Australas. J. Anim. Sci. 27:965-973.

Zhou, W., E. T. Kornegay, M. D. Lindemann, J. W. G. M. Swinkels, M. K. Welten, and E. A. Wong. 1994. Stimulation of growth by intravenous injection of copper in weanling pigs. J. Anim. Sci. 72:2395-2403. 